\title{
Beyond networks and macro-scale analysis: unravelling micro-histories of pottery at Early Bronze Age Samos, Greece through an integrated methodology
}

Sergios Menelaou

https://doi.org/10.17234/METARH.2019.4

Koç University

Research Center for Anatolian Civilizations

(ANAMED)

İstiklal Caddesi No: 181

Merkez Han

TR - 34433 Beyoğlu

P.O.B. 260 istanbul

Department of Archaeology, University of Sheffield

Minalloy House

10-16 Regent Street

GB - S1 3NJ Sheffield

sergioslim89@hotmail.com

The study of pottery has historically served as a testing ground for archaeological theories, both due to its abundance in the archaeological record and its multifaceted use in the development of various methodological tools for the investigation of issues of exchange and external influence, technological tradition, social organisation, economic trends, and other cultural associations in past societies. Nevertheless, ceramic studies have largely extended the range of tools and techniques beyond traditional approaches that focus on stylistic, morphological, and typological attributes aiming at constructing chronological sequences or reconstructing large-scale networks of interaction. In fact, recent years in Aegean studies have witnessed an increasing concern towards the technological significance of pottery and its social context from a rather scientific-processual perspective. The project of Early Bronze Age (EBA/EB) Heraion on Samos Island, east Aegean (Greece) has successfully demonstrated that questions of ceramic production, consumption, and distribution can be meaningfully approached through the integration of different scales and levels of analytical enquiry. This has been achieved following a chaîne opératoire approach and the combination of various levels of analysis from typology, phasing, and contextual study of the entire ceramic assemblages covering the third millennium BC, with macroscopic analysis, thin section petrography, and microstructural analysis. This paper provides a brief overview of specific aspects of this project with the aim to highlight the significance of adopting a holistic approach in ceramic studies of well-defined, insular prehistoric environments.

Keywords: ceramic analysis, micro-scale, technology, provenance, Samos, Aegean, Early Bronze Age 


\section{Introduction}

Despite continuous developments in ceramic studies in many areas of the Aegean (especially Crete and the Cyclades) and Greek prehistoric Archaeology in general, the ever-growing amount of data and new projects in the eastern Aegean and western Anatolian littoral region have followed a more conservative trajectory. In fact, the study of pottery in what forms today's political borders between Greece and Turkey (Fig. 1) is still largely used for its stylistic, morphological, and typological attributes with the aim to construct chronological schemes (cf. Rice 1996 with references; Orton and Hughes 2013: 3-12), determine the geological/geographical provenance based on a simple equation of similarities between pottery classes or even to reconstruct large-scale networks of interaction. However, in recent years there have been notable attempts to overturn this with the initiation of more interdisciplinary projects (cf. Alram-Stern and Horejs 2018a) that involve the application of archaeological scientific methods and less commonly the characterisation of technological practices and reconstruction of changes and/or continuities in the ceramic manufacturing process, as is commonly the case in the established research tradition of EBA Crete (e.g. Wilson and Day 1994; Day et al. 2006; Mentesana et al. 2019).

The integration of new methodologies in ceramic analyses (Tite 1999) has followed the example of projects carried out since the 1980's in a more systematic manner in the central and southern Aegean (Day et al. 2006; Hilditch 2018 with references on previous work; Papadatos and Nodarou 2018 with further bibliography), which have successfully demonstrated that questions of production, consumption, and distribution of pottery can be approached in a more meaningful way and old assumptions should be challenged through new studies of archaeological material. Recent synthetic works and case studies on various cultural/geographical regions tend to integrate traditional and modern aspects of pottery studies (e.g. Orton and Hughes 2013; Hunt 2016; Ownby et al. 2016; Sibbesson et al. 2016). This shift towards a combination of robust analysis with traditional approaches has proved to be favourable, as it integrates aspects of typology, context, and technological reconstructions with the aim to reveal cultural changes.

The almost complete absence of integrated, archaeometric projects from the eastern Aegean has impeded a better understanding of the island societies (Lemnos, Lesbos, Chios, Samos) often thought of as intermediaries in the transmission of finished products, ideas, and people from East to West, i.e. from Anatolia to the central and west Aegean, on the basis of geographical proximity. Nevertheless, this hitherto absence of such projects has been challenged by the holistic study of the third millennium BC pottery from the island of Samos. This paper employs an integrated ceramic analytical programme at the island settlement of Heraion (Menelaou et al. 2016; Menelaou 2018), focusing on the methodological aspect of this research and its articulation with a well-informed archaeological and theoretical background. A case study of the full characterisation of one of the main fabrics recovered at Heraion is presented with the aim to stress out the effectiveness in using a micro-scale approach as a means for analysing intra-site developments of a ceramic system, craft traditions and technological choices over time, as well as to gain a better insight in the consideration of provenance.

\section{Beyond the (re)construction of macro-scale Aegean-Anatolian networks}

Until relatively recently the reconstruction of patterns of regional and interregional trade and interaction was the primary focus of prehistoric Aegean and Anatolian ceramic studies, being tested further in archaeometric works through chemical/elemental analysis and the employment of a range of mineralogical and geochemical methodologies and identification of reference groups (Day et al. 1999; Day and Kilikoglou 2001). The identification of ceramic provenance has been particularly central in the reconstruction of trade networks and exchange patterns (Tite 1999: 202-203), following theoretical assumptions that favour the circulation of certain wares or vessel types in the explanation of socio-cultural or economic changes.

Narratives and concepts of large-scale exchange networks, cultural interaction and connectivity, and technological transfer, alongside developments in craft technology and specialisation, distinctive patterns of production and consumption, and increasing complexity comprise the main characteristics commonly considered to be reflected in the material culture of the third millennium $B C$ in the region under examination (cf. Kouka 2002; Şahoğlu 2005). Pottery has held a key position in investigating these issues, mainly through typological and morpho-stylistic analyses, often creating assumptions of a deterministic nature that favour the identification of similarities in style and shape between different sites.

Following the various intellectual developments of Aegean Archaeology, a number of popular theoretical models have been put forward in the study of connectivity 
and mobility (Knappett and Nikolakopoulou 2015; Knappett and Kiriatzi 2016; Alram-Stern and Horejs 2018b: 11-12; Leidwanger and Knappett 2018). More particularly, within the context of the culture-historical approach, the notions of trade, migration or diffusion of culture were usually invoked to interpret material similarities or differences, and exogenous factors were seen as the trigger for these changes. As such, the concept of cultural koine was - and still is - particularly popular. This is highlighted by Kouka (2002: 299; 2015: 230), who speaks about a "cultural koine, which was recognized in the east Aegean islands and western Anatolian littoral from the 4th through the 3rd millennium $\mathrm{BC}^{\prime \prime}$ and further exemplified by Horejs (Horejs et al. 2018: 41) in her work on Aegean-Anatolian networks "from the presence of common styles and techniques of the eastern Aegean koine, communities in this region were integrated into greater networks of the eastern Aegean and western Anatolia". Despite its usefulness in grouping together particular classes of material culture over wide geographical areas, the concept's connotation to shared 'cultures' and macro-regional processes or even identities (Galanakis 2009) runs the risk to dismiss the importance of complex and varied micro-scale social processes and the conscious role of the agents (including producers and consumers) involved in such dialectics. Thus, favouring the notion of cultural homogeneity in the material expression, at the expense of a coherent picture of small-scale developments at a local level, seems somewhat challenging.

On the other hand, the world-systems model was introduced in the archaeological theory, with adaptations of the more general sociological and economically-driven concept and terminology established in the 1970s (Rice 1998: 45-47), of which most popular is the core/centreperiphery approach. Its utility for conceptualising largescale interactions during prehistory and its deficiencies have long been discussed in the context of post-colonial theory and critiqued of neglecting the agency of the individual or even inappropriately applied (cf. Stein 1998; Kohl 2011: 79-82). This is particularly prominent in the investigation of contacts and exchanges between insular and mainland sites. The eastern Aegean and western Anatolian region constitutes a good case study in the identification of such core-periphery archaeological interpretations, where the islands only a few kilometres away from the Anatolian mainland have been largely overlooked on their own right and instead have been typically approached as being peripheral and passive in the adoption of novelties (cf. Menelaou 2018).
Network Analysis comprises another popular approach in the identification of similarities in material culture between different regions, usually concerned with the detection of trade patterns in a regional and interregional scale and variations in social and economic structures. This model largely follows an economic and environmental determinism, according to which communities need to interact with one another to promote change in social, political, and economic aspects. Networks are expressed through graphs with connecting points between sites that represent nodes or links. Although widely used and while these models provide useful visualisations for the reconstruction of macro-scale narratives, current network theory is in some ways a poor fit for networks of the ancient past (Knappett 2013: 7-10). Especially in the case of maritime interaction and connectivity models, the environmental and social factors that facilitated travel and communication in the Aegean (e.g. distance, geographical proximity, weather conditions, technologies of mobility, skills in navigation, etc.), as highlighted by Tartaron (2018: 62), cannot be captured by simply drawing lines and links between different geographical nodes. Frontiers and boundaries between sites and regions are dynamic, often unpredictable, and can be easily transformed over time. Nevertheless, Broodbank's (2000) work on the EBA Cycladic interaction networks, using a proximal point analysis, demonstrated an ideal case study for modelling intra-regional, maritime smallworld connections.

This brief theoretical background highlighted just a few of the methodological and interpretational attempts to conceptualise large-scale interaction. A caution is provided against a 'top-down' detection of connectivity and the process of identification of common patterns, while a shift to emphasis to the local, micro-regional scales seems imperative in order to better comprehend the cause of the intensification of interactions during the third millennium BC. This can be achieved or at least approached more tangibly - in the case of pottery - with the combination of integrated methodologies (traditional/archaeological and analytical/archaeometric) with a well-informed theoretical framework. In the case of ceramic materials, what can be identified are the source (geological/geographical provenance) and the final consumption place. Islands are ideal case studies for exploring such dialectics of space and circulation, as they provide well-defined units of investigation. 


\section{Archaeological context and geographical setting}

The position of Samos in the eastern Aegean (Fig. 1) which includes the offshore islands (Lemnos, Lesbos, Chios, the Dodecanese) and the opposite Anatolian coast, have been overwhelmingly neglected within Aegean-Anatolian prehistoric Archaeology (Kouka 2002; Şahoğlu 2005; Horejs 2017), in contrast with the western, northern, and southern Aegean, where the material record has been intensively investigated. A similar pattern is also observed in the representation of archaeometric projects in this region. Nevertheless, this region forms a significant interface between the Aegean basin and the Anatolian plateau, itself linked through long-distance exchange with the early urban complex societies across the Eastern Mediterranean.

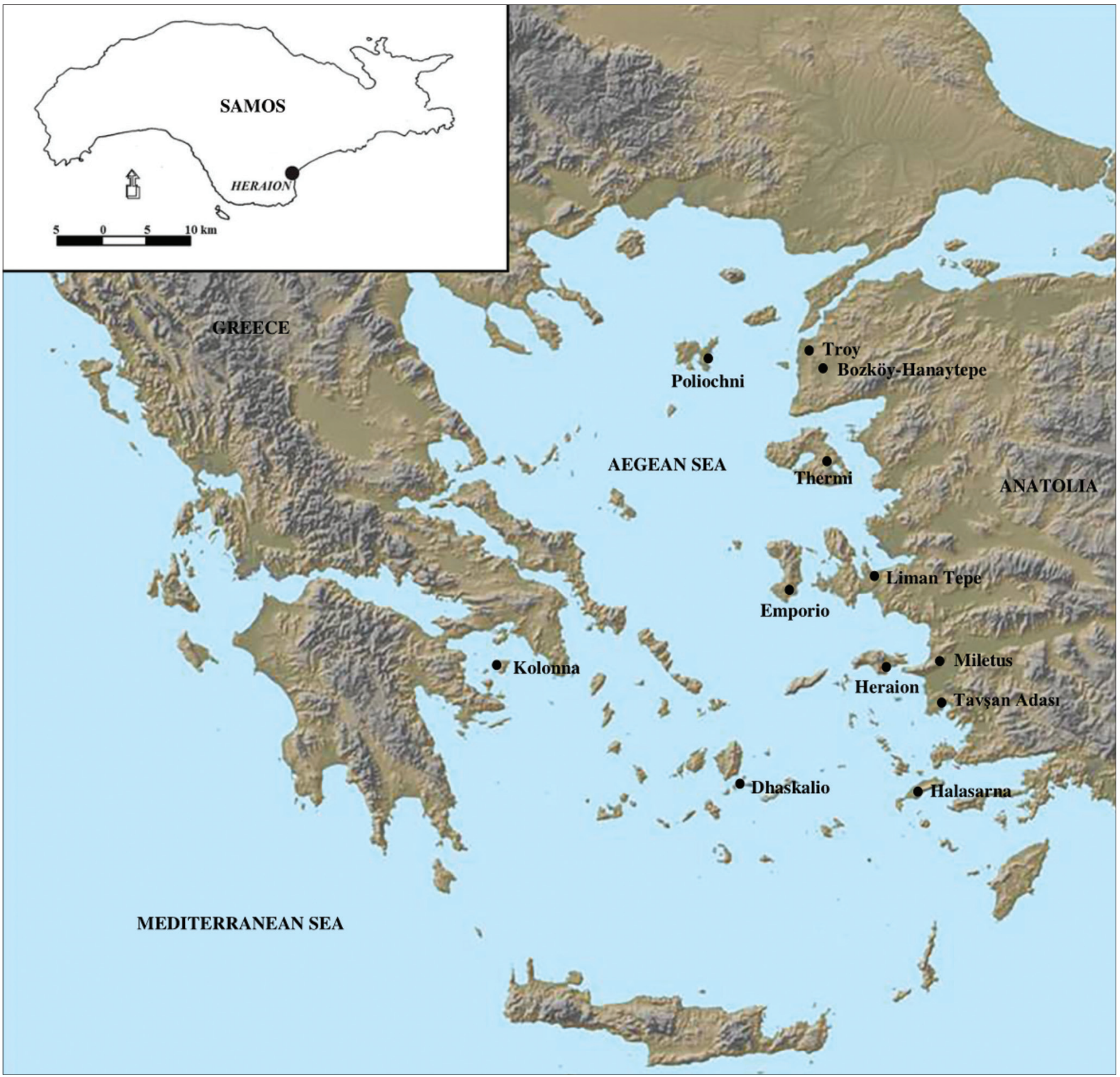

FIGURE 1. Map showing Heraion on Samos and selected sites mentioned in the text. 
Samos Island is situated in a very advantageous geographical area, on a maritime artery that links communication networks between East and West, and perhaps should be seen as a 'bridge' between western Anatolian littoral - Çukuriçi Höyük, Miletus, Liman Tepe, Tavşan Adası so to name a few contemporary sites with Heraion - and the Cycladic islands or even the west coastlands of Mainland Greece. In her thorough study of the network of maritime communication routes in the Aegean during the Neolithic and the EBA, Papageorgiou (2002) proposed that two main routes/passages facilitated the communication between Samos and the rest of the Aegean. More particularly, Samos is the last landfall before the Gulf of Kuşadası, if one is following the Route B and is sailing from the South, crossing the passage between the islands of Rhodes, Kasos, and Karpathos, as well as the passage between the Dodecanese and the Cyclades (Papageorgiou 2002: 163-164, 303-321), and the first on the principal route (Route Z) from Asia Minor to the central Aegean and Mainland Greece or in reverse (Agouridis 1997: 8). Samos, due to its nodal position in the eastern Aegean, is assumed to constitute the geographical and cultural link between western Anatolia and the central Aegean during EBA. Particularly important in this communication are the two arteries extending from the interior of Asia Minor: the Gulf of Ephesus northeast of Samos formed by the Kaystros or Küçük Menderes River, and the Meander Valley to the southeast formed by the Büyük Menderes River (Papageorgiou 1997: fig. 4).

This paper focuses on the Heraion settlement, which is situated on the south-central plain of Samos, the most fertile area on the island (Kouka and Menelaou 2018: fig. 1). The historiography of past research projects and excavations carried out at prehistoric Samos and Heraion, in particular, are presented in detail elsewhere (Kouka 2015: 224-225; Menelaou 2015: 25; 2017: 181-182; Menelaou et al. 2016: 482; Kouka and Menelaou 2018: 119121).

The results briefly discussed in this paper derive from a combined analysis of three different ceramic assemblages excavated at different times and different areas of the settlement. More particularly, pottery excavated by Milojčić (1961) in the 1950's in the area between the Hera Temple and the North Stoa, as well as underneath the Pronaos that dates to the second half of the third millennium BC (phases Heraion I-V which correspond to EB II mature/developed through EB III late); by Weisshaar and Kyrieleis in 1981 north of the Sacred Road which revealed four architectural phases dating to EB I and EB II early (with earlier evidence dating to the Chalcolithic/Ch; Kyrieleis et al. 1985: 409-418, figs. 35-
43; Kouka 2002: 286, tab. 1); and the pottery from the recent excavations undertaken by Kouka (2009-2013) in trenches immediately to the north of the later investigations (Kouka 2015: 225-228, figs. 1-3; 2017: 163-167), corresponding to five architectural phases, that revealed a continuation of the settlement from the $\mathrm{Ch}$ to the end of the Middle Bronze Age. The combination of all aforementioned ceramic assemblages at Heraion has allowed the formation of a complete ceramic sequence with no chronological gaps (Kouka and Menelaou 2018: tab. 1). Since previous studies of EB ceramics from Heraion have focused on establishing a relative chronology and a basic typology for comparisons with the rest of the East Aegean, based mainly on stratigraphical observations and variation in morphological and stylistic terms, the present paper provides a good opportunity to examine how different aspects of a ceramic system articulate with each other.

\section{Methodological framework}

Having established the theoretical and archaeological background of this project we can now move on to the methodological significance of this paper. The almost complete absence of such work at the eastern Aegean and Samos, as well as recent access to suitable ceramic datasets from the old and the new excavations at the Heraion settlement, has enabled the author to test methodologically the significance of micro-scale analysis at a well-defined insular place.

The present project has focused on analysing the full spectrum across the assemblages, i.e. the range of wares, fabrics, and shapes, an approach that has been extensively developed by Wilson's and Day's work in Crete (cf. Wilson and Day 1994; Wilson et al. 1999). Initially, this has been achieved through phasing and contextual analysis which enabled a good understanding of the local chronological sequence of the settlement (cf. Kouka and Menelaou 2018). This project builds upon various levels of analysis in the context of whole assemblages including:

a) Morphological examination at a macroscopic level, namely the examination of pottery by the naked eye and with the aid of a USB Digital Microscope, and its stratigraphic classification into wares, fabrics, and shapes/ types in a diachronic manner. This allowed us to identify technological stages such as raw material choice, paste preparation, forming techniques, surface treatment modes, and firing, examined in accordance with typological patterns and morpho-stylistic features. The 
macroscopic analysis enabled a first, preliminary characterisation of local and suspected non-local fabrics, and quantification of their diachronic frequency was made.

b) Petrographic analysis of a large number of representative samples selected on the basis of macroscopic features, covering all periods, wares, and macroscopic fabrics (see Whitbread 2016 for description process). Ceramic petrography, namely the microscopic examination of ceramic thin sections, allows the identification and characterisation of the main mineral and rock types comprising the non-plastic inclusions (composition, quantity, shape, grain size and distribution), the examination of the optical properties of the clay matrix and the assessment of the textural associations of the above components (microstructure, colour, optical activity), which in turn enabled characterisation and grouping of the thin sections, reconstruction of technological practice (raw material processing and clay preparation, firing characteristics, forming techniques), and, where possible, the suggestion of provenance (geological and/ or geographical).

c) Petrographic examination of both published and unpublished comparative material from predominantly contemporary sites across the Aegean and western Anatolia.

d) Microstructural analysis via Scanning Electron Microscopy-Energy Dispersive X-ray Spectroscopy (SEM-EDS), which established the micromorphological characterisation of the fabrics and surface of the samples under examination (firing temperature, surface treatment, microstructure). Such data can provide information on the types of clay used for slips in comparison to the composition of the body.

e) Geological prospection including the identification of potential raw material sources, collection and experimental analysis (ultimately by petrography) of clays, following the careful examination of Samos's geological background. Their comparison with the ancient pottery fabrics allowed the suggestion of geological and geographical provenance. This was also supported by an ethnographic study and examination of modern ceramics and tiles or bricks from kiln sites across the island.

f) Chemical analysis with Wavelength Dispersive X-ray Fluorescence (WD-XRF) is currently in progress. Bulk chemistry was not employed during the original stage of the analytical work, but a relative estimation and assessment of local versus non-local fabrics was made through a combination of contextual, macroscopic, and petrographic information.
This research project employed a theoretical approach which concentrates explicitly on the social dimensions of technological practice, according to which technology is a socially constituted dynamic process of combined social and material engagement (Dobres 2000: 125). Following a chaîne opératoire approach, an attempt to reconstruct all stages of the manufacturing process was made and a more detailed view of local developments has been gained. This popular approach in ceramic studies concentrates on the step-by-step reconstruction of the related past technical system and the social, cultural, and economic acts in the process of making and transformation of raw materials to a finished product affecting the potters' actions in the manufacture of pottery (e.g. Lemonnier 1993; Roux 2016). It, therefore, represents a shift away from solely morphological and stylistic patterns of object-driven approaches. Therefore, for every step of the manufacturing process different techniques were applied. Not all manufacturing steps are reconstructed equally, i.e. the fabric characterisation, processing of raw materials, surface treatment are better studied, whereas the interpretation of forming methods and firing conditions varies in confidence, depending on the available data.

Two basic insights were achieved:

1. The identification of patterns in the ceramic manufacture and technology at a local level, which enabled the reconstruction of the operational sequence of the pottery production process through the chaîne opératoire approach. This micro-scale analysis allowed the reconstruction of choices made by individual potters and workshops, the diachronic transmission of technical skills, crafting choices, and the emergence of local technological traditions and ceramic styles.

2. The examination of stylistic, typological, and fabric influences, as evidenced by macroscopic and microscopic features, and thus the determination of provenance, where possible, through the identification of the geological and/or geographical source of raw materials.

\section{Reconstructing the operational sequence of a ceramic group from Heraion}

The wealth of ceramic evidence at Heraion has offered the potential to explore intra-site technological practice, as well as inter-site relations at a regional level through a comparative examination of thin sections from other sites and extensive bibliographical research on form/finish/fabric comparanda and vessel parallels from across the Aegean and Anatolia during the Ch-EBA. This section 


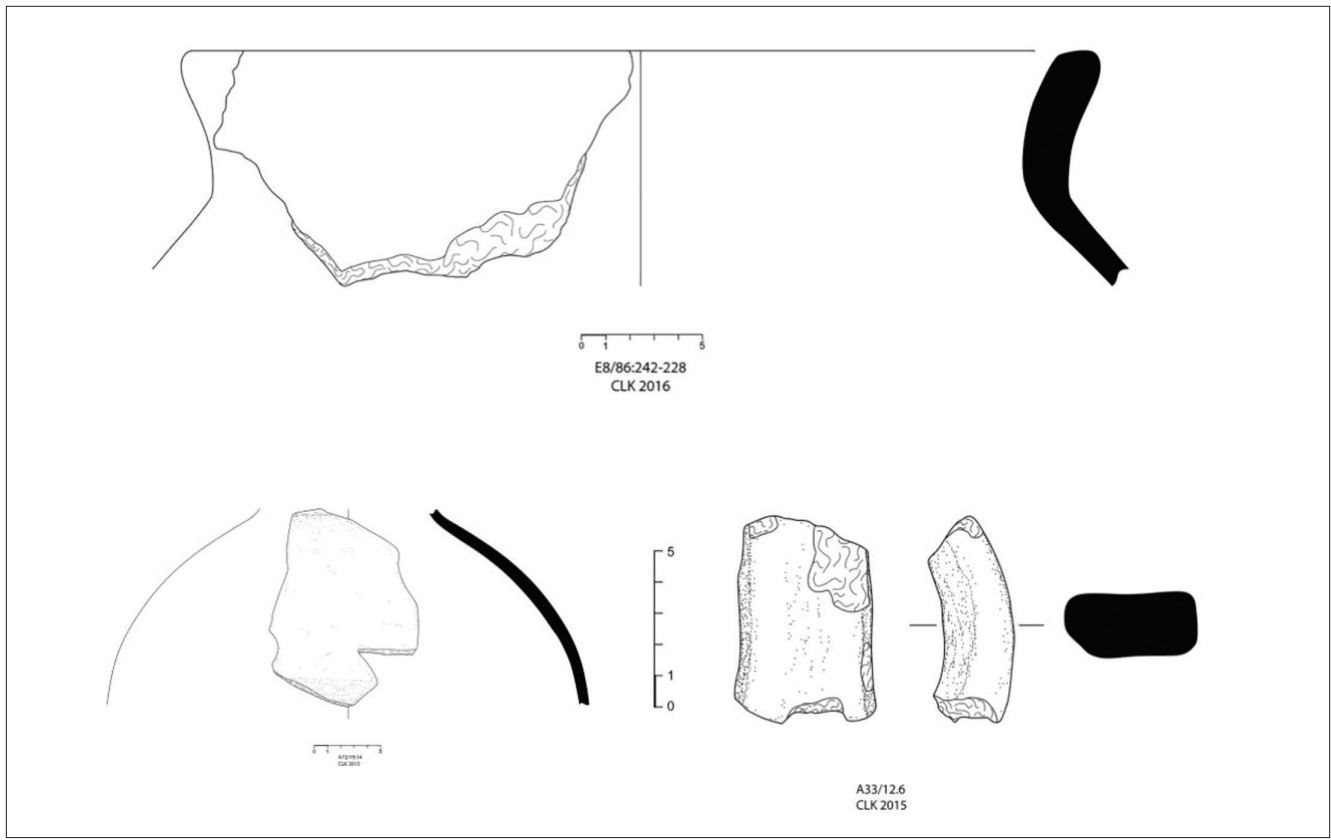

FIGURE 2. Illustrations of selected storage jars from Heraion. deals with selected data from the overall holistic study (Menelaou 2018). Preliminary observations, mainly typological and morphostylistic, have been presented in short studies in a diachronic manner, alongside contextual, architectural, and chronological information (Menelaou et al. 2016; Kouka and Menelaou 2018; Kouka et al. forthcoming).

The systematic diachronic study of pottery from Heraion has produced significant patterns of production and exchange. Regarding pottery production, the variation in fabrics and distinct technological features within each implies that there must be several production centres operating in parallel in the vicinity of the site or some perhaps beyond the environs of Heraion itself. The majority of the pottery dated to the early phases of the EBA fall into the metamorphic fabric(s), which comprise more than half of the total analysed samples. These might reflect both a number of workshops and varied raw material sources in the vicinity of Heraion. Combined with the macroscopic information, the petrographic analysis revealed some important associations between shape, assumed function, fabric, and ware. From the diachronic examination of fabrics versus shapes, it appears that no differentiation can be detected between clay recipes used for large or medium/small-sized vessels or warespecific groups in the Ch-EB I periods. In the subsequent period, there emerges a more varied picture with fabrics used for the manufacture of particular vessel types or even a range of similar fabrics that could reflect the existence of several production centres that produce the same types in similar or different recipes (Menelaou 2015; 2017; Menelaou et al. 2016). This could point out distinct manufacturing traditions and markedly different clays that can be explained from a chronological and technological perspective. Furthermore, the integration with macroscopic results has enabled the establishment of a detailed basis for the characterisation of the local ceramic technological tradition and the reconstruction of potential links of interactions with other Aegean and Anatolian sites through a detailed contextualisation of Samos within a regional framework from the $\mathrm{Ch}$ to the end of the EBA (Menelaou 2018).

Within this framework, this paper examines one ceramic class and some of the key trends deriving from its analysis. The chaine opératoire approach is applied, and it is attempted to reconstruct all technological stages of the manufacturing process from raw material collection and characterisation of the clay composition to forming, surface treatment, and firing. Finally, the geological and geographical provenance is suggested within an intra- and inter-regional context. The various analytical methods are discussed where appropriate within each sub-section. The following discussion is broken down into five separate stages from the procurement and collection of the raw materials for pottery manufacture to finished products and their morphological characteristics. The 'Porphyritic Intermediate Volcanic Rock Fabric Group' (Menelaou 2018) corresponds predominantly to EB I-II developed storage vessels, i.e. wide-mouthed open jars/ deep bowls, pithoid jars with vertical handles of a circular or oblong cross-section and usually a collared neck, as well as larger vessels with circular handles that can be characterised as pithoi (Fig. 2). 


\section{Clay composition and raw materials preparation}

This fabric group was first characterised macroscopically due to its distinctive hard texture and coarse petrology and subsequently described in detail petrographically. It is characterised by a medium-coarse/coarse clay paste with reddish yellow/reddish brown (5YR 6/6, 2.5YR 6/6) matrix, usually exhibiting a core-margin differentiation of dark grey/black (7.5YR 5/1) and reddish yellow/red (5YR 6/6) colour respectively. Its main petrological features comprise of frequent to common, sparkling golden angular to sub-angular inclusions, fine to medium angular dark translucent/glassy inclusions, chalky-white fragments, as well as a frequent amount of organic temper (Fig. 3). In petrographic terms, these were identified predominantly as volcanic rock fragments of intermediate composition (andesite grading into dacite) and their constituent minerals (varying amounts of plagioclase feldspar, amphibole, biotite, pyroxene, quartz). In almost all samples there is a considerable amount of burnt-out vegetal temper appearing as elongate voids. It is overall a homogeneous, very consistent fabric group in terms of composition, although there are minor differences between samples. Despite some variability with respect to coarseness and roundness/angularity of the non-plastic inclusions, their range in both size fractions indicates that a relatively unprocessed clay consistent with in situ weathering was most probably in use, with the finer examples representing a better-processed paste.
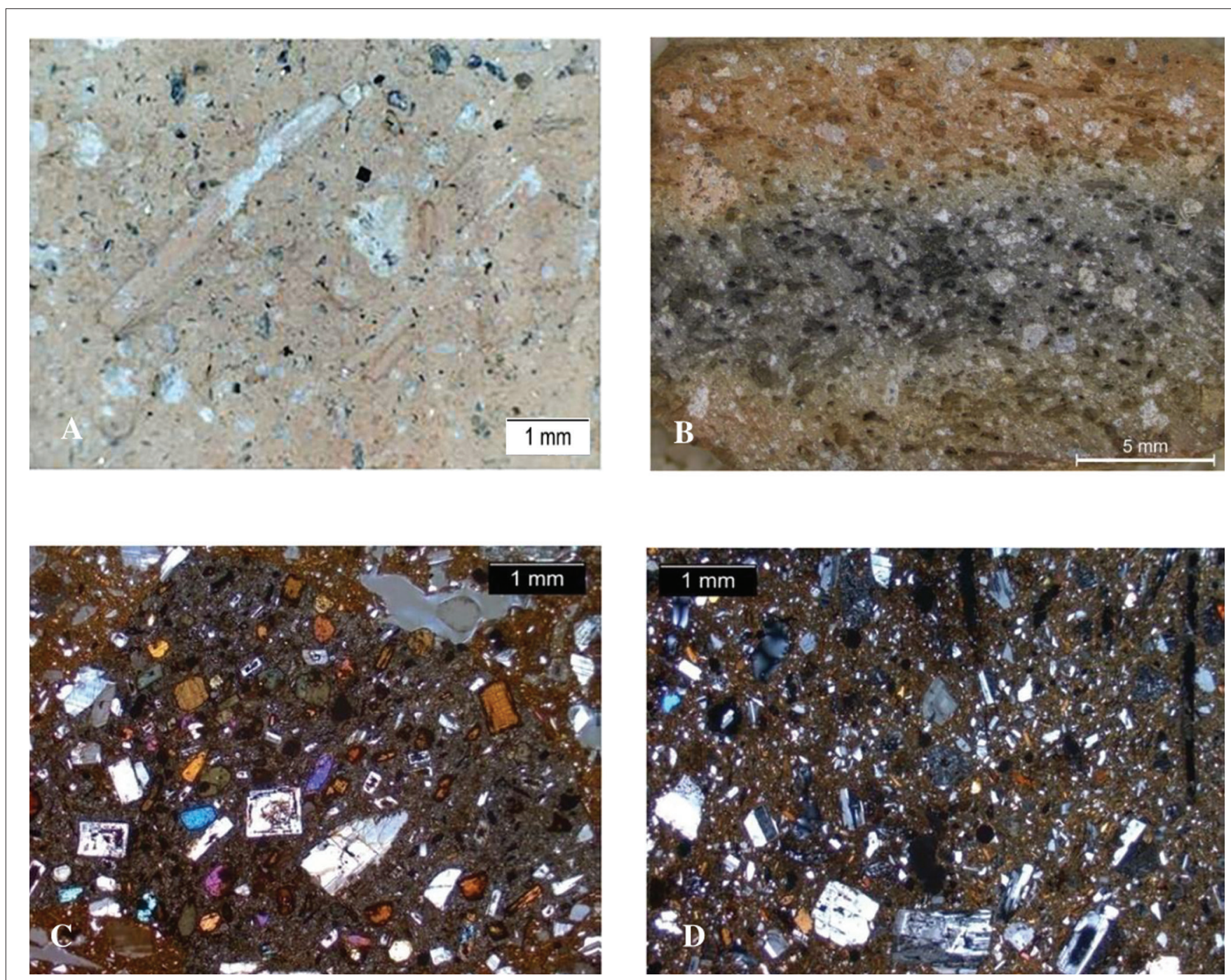

FIGURE 3. Fabric photographs of selected samples. A-B. Macrographs taken with a USB Handheld Digital Microscope; C-D. Micrographs taken in crossed-polars with a petrographic microscope. 


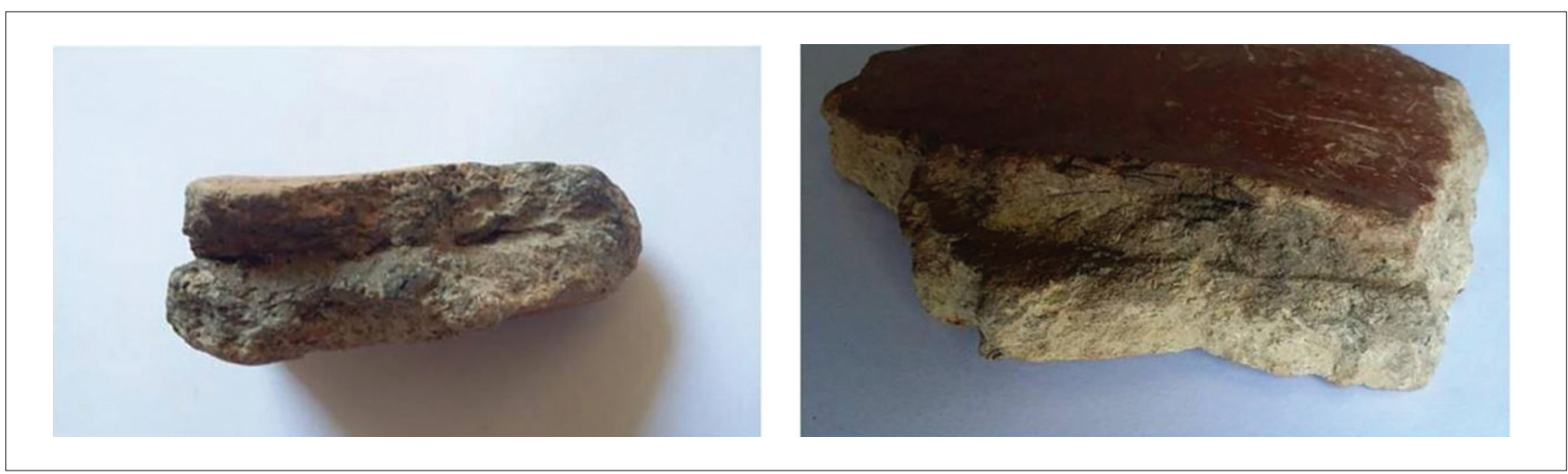

FIGURE 4. Ceramic body sherds exhibiting clay layering (photographs taken by S. Menelaou, no scale).

\section{Forming techniques}

Although surface modification often affects the visibility of the forming and finishing techniques employed, including the orientation of inclusions and voids, some examples provide evidence for the identification of handbuilt methods. More particularly, some sherds exhibit evidence for, what is preliminarily believed to be, the use of slab-and coil-building methods, according to the identification of distinct superimposed layers of clay. This is more clearly identified macroscopically in body sherd sections, but can be better observed close to rims or handle attachments and the base of the pots, where the wall is thicker (Fig. 4). The slabs/flattened coils are identified petrographically by elongate voids or the differential orientation of inclusions created upon the formation of the vessels (Fig. 3D). Similar techniques, namely sequential slab construction or multi-layering methods, have been identified in the Neolithic and Chalcolithic central Zagros region and the Iranian plateau (Vandiver 1987: 20), and more recently also at Pre- and Protopalatial Phaistos in Crete (Todaro 2018). Ceramics made with this technique are also linked with the use of vegetal tempering, which affects the plasticity of the clay.

\section{Finishing and surface treatment}

The examination of surface treatment and finishing techniques was achieved mainly by macroscopic examination, combined with SEM study of the microstructure. This fabric group is associated with well-slipped and burnished vessels which stand out due to the quality of their red (10R 5/6) - or rarely black - non-calcareous surface finish (Fig. 5A-C). Some examples were also identified petrographically (Fig. 5D). The iron-rich slip layer, also confirmed by the high Fe spectrum values of the EDS analysis, ranges in thickness $(0.02 \mathrm{~mm}$ to $0.04 \mathrm{~mm})$ and is clearly separated from the clay body (Fig. 5E-F). The majority of vessels appear with a lustrous surface and have only their exterior slipped and burnished, while their interior surface exhibits a characteristic scored treatment (Milojčić 1961: pl. 31:2; Kouka and Menelaou 2018: 127). Scoring is shown by parallel horizontal or perpendicular striations which appear more regular below the rim (Fig. 5B); occasionally these are oblique and overlap with each other. More rarely, the creation of burnished interior surfaces may relate to the utilisation of the vessels to hold liquid or foodstuff. Given that burnishing and the creation of a lustrous surface is particularly timeconsuming it is more likely to suggest that it relates to a decorative habitus and tradition of the producers of these vessels, or even acted as a sign of quality, rather than just serving functional purposes.

\section{Firing procedure}

Macroscopic observations have established a first understanding of the firing regime of this pottery group, based on colour and variation of the sherd breaks, combined with a comparison of colour and optical activity of the micromass in petrographic thin sections (Fig. 5D). However, more secure information was extracted from the SEM analysis. The majority of samples show a pronounced colour differentiation with a darker core that relates to the common presence of partially-combusted vegetal temper. This effect could either imply a fast- 

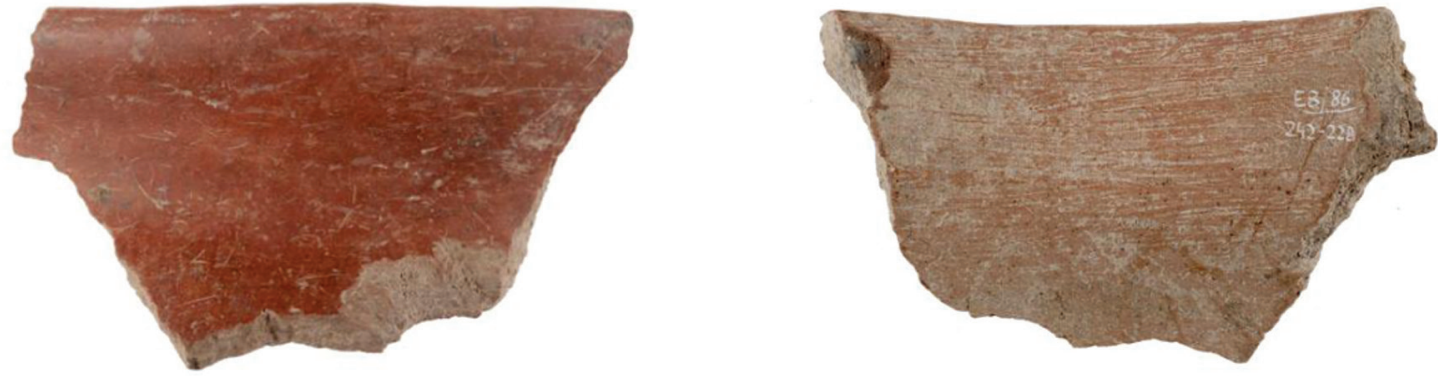

A

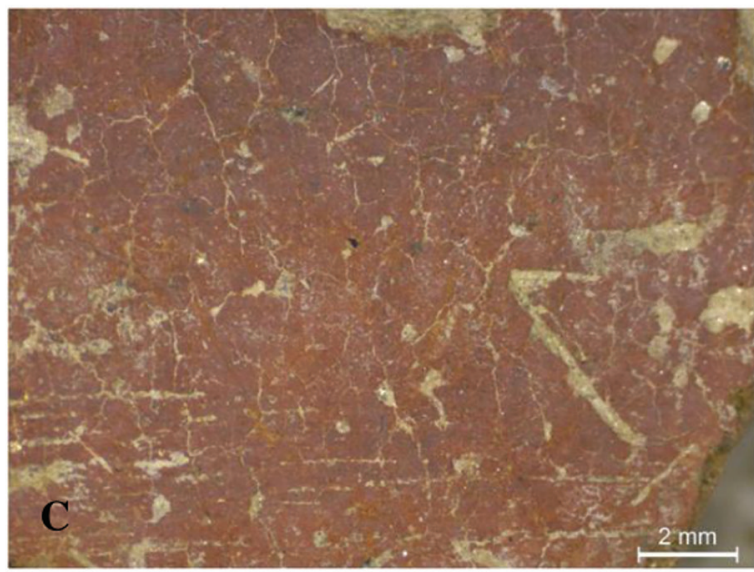

B

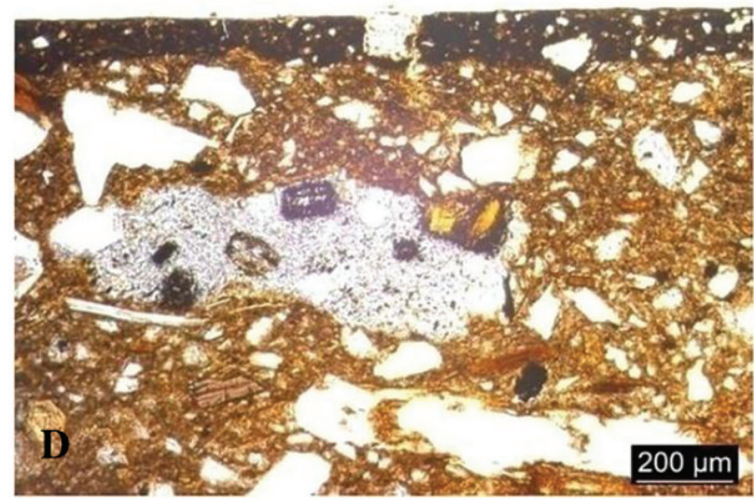

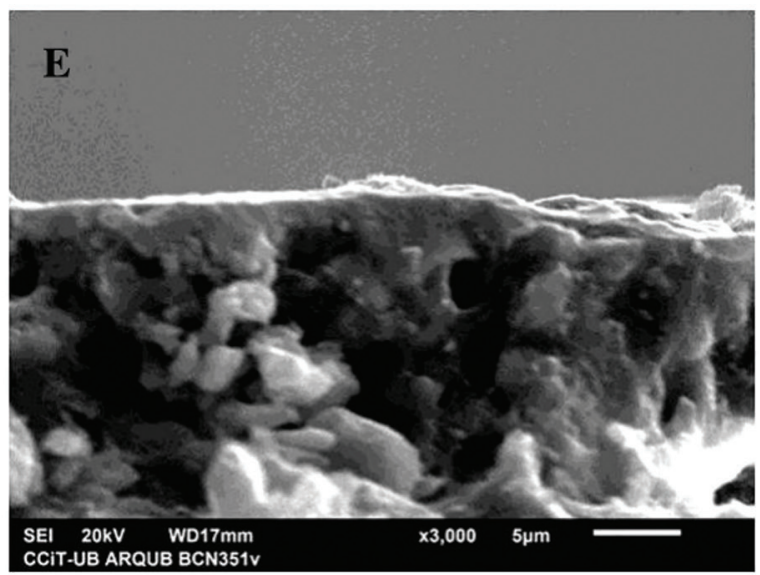

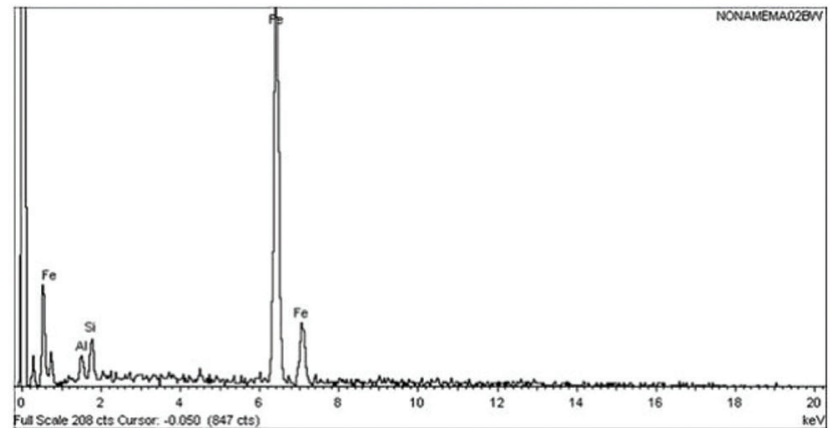

$\mathbf{F}$

FIGURE 5. Examples of the red slipped and burnished vessels and surface treatment examination. A. Exterior surface of a storage jar with a lustrous thick slip; B. Interior surface of a storage jar with traces of scoring; C. Macrograph of the surface treatment mode; D. Micrograph of the exterior slip layer; E. Slip layer identified with SEM; F. SEM-EDS element spectrums showing a high amount of Fe on the slip surface (all images taken by S. Menelaou).

firing process, perhaps in an open environment, where the carbon deposits were allowed to build up through a complete lack of oxygen. However, the firing was too short for the process to complete full oxidation (Kilikoglou and Maniatis 1993: 438). SEM analysis suggested that almost all samples - except for one or two dated to the later EBA phases - were low-fired and thus appear to be non-vitrified, but some rounding on the edges of the clay pastes occurs, and this is defined as an intermediate stage between no vitrification and initial vitrification with an estimated temperature of $750-800^{\circ} \mathrm{C}$. 


\section{Morphological features}

The main vessel types forming this group are the widemouthed open jars and the pithoid jars/pithoi. The former type is characterised by straight walls and a usually thickened rounded rim with a wall thickness between $0.9 \mathrm{~cm}$ and $1.5 \mathrm{~cm}$ and a rim diameter of $25 \mathrm{~cm}$ to $36 \mathrm{~cm}$. Its form and style find close typological parallels at Emporio V-IV on Chios (Hood 1981-82: 359-360, fig. $164: 888)$ dating to EB I. The latter type is characterised by a collared neck or funnel-necked profile, being slightly flaring or carinated on the inside. The upper part of the rim is usually rounded or flattened. There are two types of vertical handles, i.e. oblong or sub-rectangular and circular in cross-section. The thickness ranges from $1.3 \mathrm{~cm}$ to $2.2 \mathrm{~cm}$ for the body, $2 \mathrm{~cm}$ to $3.2 \mathrm{~cm}$ for the rim and the rim diameter ranges from $24-26 \mathrm{~cm}$ to $36-40 \mathrm{~cm}$ for the larger vessels. Typological and stylistic parallels have been identified at Troy II, Poliochni Blue-Green corresponding to EB I-II early (Bernabò Brea 1964: LIV:f, LXXVII:f, g, i) and Emporio IV-II on Chios corresponding to EB I-II late (Hood 1981-82: figs. 187:1284-1285, 12901292). Other, minor vessel types in this fabric identified at Heraion are the winged jar and the steep-necked jug with a long cut-away spout. The former is typical for Troy II late (EB II late), Aphrodisias BA 4 corresponding to EB IIIA (Joukowsky 1986: 394, figs. 327 and 426.4) and Poliochni Yellow on Lemnos corresponding to EB II late (Bernabò Brea 1976: pls. CXCIV, CVCV:b,e). The origin of the steep-necked jug has been attributed to southwest Anatolia and close typological parallels are known from Troy III-V corresponding to EB III (Blegen et al. 1951: 29, pls. 59a: Shape B20, 72:33.179), in late EB II-early EB III contexts at Bakla Tepe (Şahoğlu 2008: 157, fig. 2g), Poliochni Yellow (Bernabò Brea 1976: pl. CCX:C) and EB III Vathy on Kalymnos Island (Benzi 1997: 386, pl. 2b:5722).

\section{From micro-histories to macro-narratives}

The presentation of this distinctive ceramic group from Heraion and the reconstruction of all stages of its manufacture have allowed meaningful insights into the technology and provenance of vessels, otherwise studied in terms of their shape and surface treatment (Milojčić 1961: 40, pls. 31:2 and 48:35). The combination of technological information, from clay composition to firing, suggested a potentially non-local provenance for this group that is primarily consisted of large storage jars and pithoid jars/pithoi dating to EBA I-II early and less commonly to EB II late-III periods. The first evaluation of this pottery group implied a local production both due to its frequency and diachronic span at the settlement, but a more careful examination of its technological features, compared to other Samian groups that have been confidently ascribed with local provenance, further suggested a most likely off-island provenance. This was also supported by observations based on geological literature, supplemented by raw material prospection and experimental analysis of clays and sediments from Samos, which did not identify any possible correlations with the on-island geology. Overall, the composition of this fabric is not diagnostic for Samos. The limited Neogene volcanic bodies that penetrate the metamorphic substrate in the margins of the Mytilinii basin are characterised by basaltic tuffs and minor trachydacites, while more acidic lavas and rhyolitic tuffs occur in the Karlovassi basin (Menelaou 2017: 184-185).

An extensive, but not exhaustive, fabric, style, and shape/type study of pottery from contemporary Aegean and Anatolian sites has established some possible connections with Samos. The morphological and stylistic features provide links with a number of western Anatolian and less commonly southeast Aegean sites, but these do not allow to pinpoint the possible source of importation of these vessels on Samos. The combination of shape/style with fabric and other technological features may help narrow down the suggested geographical area of origin.

Starting from the west Aegean, this intermediate volcanic fabric is macroscopically linked with Macroscopic Group 1 or petrographically with Fabric Group 1 recorded at Kolonna on Aegina in the Saronic Gulf (Gauss and Kiriatzi 2011: 47-49, tab. 12, figs. 17, 29-31; Kiriatzi et al. 2011: 93) and the 'Dark Volcanic Macroscopic Group' from Dhaskalio on Keros (Hilditch 2013: 474, V10). Despite the strong similarities, a closer examination of the Heraion fabric revealed some important mineralogical, compositional, and textural differences with the Aeginetan fabric, on the basis of presence/absence of pyroxenes versus amphiboles and biotites.

Stronger parallels were identified in the east Aegean and western Anatolia. More specifically, potential macroscopic fabric and finish links are suggested here with the 'Obsidian Ware' from Emporio on Chios, which is thought to be imported at Chios and spans Phases VIIII (Late Neolithic to EB II) (Hood 1981-82: 168-169, figs. 187:1284-1285, 1290-1292, 204:1642). This group at Emporio is distinguished by the presence of hard, shiny, black angular particles that resemble obsidian and it corresponds to large storage jars/pithoi during Phases V-IV corresponding to EB I (Hood 1981-82: 308, 358, 434, pl. 
80 no. 1362). Similarities exist also in shape and surface treatment. The latter appears with the characteristic scoring traces, as those known from Heraion, and have been linked by Hood (1981-82: e.g. pl. 104:2397, Period II) with the 'Scored Ware' large storage jars known to have been imported in middle-late Troy I and II from further east in Anatolia (Blegen et al. 1950: 39, 53-54, 222). Similarly, the 'Early Aegean Ware' (Blegen et al. 1950: pls. 251-252, 409-410; 1951: pls. 175:15-17, Troy IV, 250, Troy $\mathrm{V}$ levels), which is presumably imported at Troy from the Greek mainland or the Cyclades, has the same characteristics. It corresponds to closed vessels with a thick red slipped exterior surface and a scored interior and it was found at Troy I-II levels. Potentially similar wares/fabrics were recently found in survey material at Bozköy-Hanaytepe in the Troad (Yilmaz 2013: 868-869, fig. 11) and Halasarna on Kos, at the latter site predominantly dated to the EB I-III, that are suggested to be locally produced (Georgiadis 2012: 24-25, 49, fig. 8:Kt.108, Kt.Lh.5-6). Other typological, and potentially also fabric, parallels have been identified at Poliochni Blue-Green (EB I-II early) on Lemnos (Bernabò Brea 1964: LIV:f, LXXVII:f, $g$, i). Perhaps similarities should also be searched with the Red-Slipped and Burnished Ware from the Neolithic site of Ulucak in the Izmir region, according to its macroscopic fabric/ware characteristics and frequency at this site (Çilingiroğlu 2012: 27-28).

In terms of clay composition and petrographic analysis, similar andesitic fabrics have been recorded in Late Bronze Age pithoi from Troy, which have been assigned with a local provenance related to the Ezine volcanic outcrops and the fluvial deposits about 10-20 km away from the site (Kibaroğlu and Thumm-Doğrayan 2013: 48-49, fig. 2d). Further petrographic analysis of pottery from Troy VI-VIIA demonstrated the common presence of altered and fresh volcanic rocks in all assumed local fabrics and vessels typologically considered as 'Island Wares' and connected to the nearby islands of Samothrace, Lemnos, and Lesbos were proven to be indistinguishable from the local Trojan fabrics (Krijnen 2014: 25). Another fabric of similar composition has been recently identified petrographically in the Neolithic pottery from Emporio and Agio Gala on Chios, which is taken as a local product on the basis of the presence of calc-alkaline andesite and basalt volcanic bodies (Pe-Piper et al. 1994). Nevertheless, the Chian fabric differs from that from Samos by the presence of fewer pyroxenes and the predominance of altered biotite and amphibole crystals (B. Lambrechts pers. comm., January 2017). The volcanic fabrics from EB Liman Tepe in the Izmir Gulf represent most likely local products and relate to volcanic bodies in the Karaburun peninsula (Day et al. 2009: 341). Its com- position and texture is similar to a local volcanic fabric at Heraion (Menelaou et al. 2016: 485, tabs. 1-2, Fabric 3: Altered Volcanic, fig. 4b; Menelaou 2017: 187-188, fig. 7). Other parallels in inland western Anatolia derive from the southwest Konya plain, which is dominated by andesitic and dacitic volcanic rocks (Gait et al. 2018: 109111, fig. 1).

Perhaps the best fabric/ware matches derive from EBA Miletus and Tavşan Adası Phase 2 (EB II late-IIIA) in western Anatolia, both of which are situated in important geographical nodes immediately opposite and south of Samos. The frequency and compositional features of these fabrics at the aforementioned sites are currently under study by other researchers (personal communication with Dr J. Hilditch and Prof. F. Bertemes) and their publication will allow a better comparison with the ceramic group recovered at Heraion. Thus, although this group is undoubtedly non-local and the potential published parallels point to western Anatolia, its provenance remains open until more comparative material and analytical results from the eastern Aegean and western Anatolian region, where similar geological formations are encountered, become available which will allow a closer geographical resolution.

A better picture of the neighbouring regions, that could represent the provenance areas of the fabric in question, is given by the geological literature. According to geochemical and petrographic analyses, the Neogene volcanic units of the Karaburun peninsula east of Chios in the Izmir region are represented by olivine-bearing basaltic-andesites to shoshonites and related pyroclastic rocks (Karaburun volcanics), high-K calc-alkaline andesites, dacites and latites (Yaylaköy, Armağandağ and Kocadağ volcanics), mildly-alkaline basalts (Ovacik basalts), and rhyolites with trachyte-like porphyritic outcrops (Urla volcanics) (Helvaci et al. 2009: 185-186, fig. 3; Ersoy et al. 2012: fig. 1). Common volcanics are also widely distributed in the areas to the north and south of the Karaburun peninsula, with the former being characterised by high-K and calc-alkaline products (Lemnos Island) and alkali basaltic lavas to the east in western Anatolia (Biga peninsula, Troas), high-K andesites, dacites, and rhyolites (Lesbos Island and the opposite coast and mainland), as well as alkaline olivine basalts, calcalkaline rhyolites, dacites, and andesites outcrops in Chios. The latter exhibits a comparable geochemical signature with northwest Anatolia andesitic-dacitic rocks (Innocenti and Mazzuoli 1972: 87), although differences occur in the composition of rhyolite outcrops (Helvaci et al. 2009: 188). Southwest Anatolia, the Bodrum peninsula area, and the Dodecanese islands of Kos, Yali, and 
Nisyros include younger volcanic rocks (Upper Miocene to Quaternary) and are characterised by trachytes, rhyolites, and basalts (Helvaci et al. 2009: fig. 2).

This case study of a single ceramic group has highlighted the interconnected nature between questions of technology and provenance in pottery manufacture, particularly prominent in the investigation of micro-scale developments of a given site. This in extension has provided a better view of intra-regional maritime connectivity and the circulation of storage (perhaps transport) jars already from the beginning of the third millennium BC, in a cultural/geographical area where interaction mechanisms and exchange networks comprise a hotly-debated topic.

\section{Conclusions}

This paper has tried to demonstrate how a micro-scale perspective, focused on the social dimensions of technology through the chaîne opératoire approach, can allow the closer examination of the potters' choices at each manufacturing stage. In extension, isolating specific technological steps and acknowledging variability can allow the discrimination between different traditions and products of different potting communities, i.e. the distinction between local and non-local pottery groups. The case study of the EBA Heraion on Samos Island has demonstrated that questions of production, consumption, and distribution of pottery can be meaningfully approached through the application of a holistic, integrated methodology combined with a sophisticated theoretical background that concentrates on the social dimensions of technological practice. Only by understanding the small-scale developments and changes in a craft practice as pottery making we can move on bigger narratives of connectivity and mobility. An integrated, diachronic analysis of total ceramic assemblages has proven to be a very effective approach, particularly when combined with the examination of comparative data from other contemporary sites. Aside from its significance in terms of an integrated, multi-technique methodology, this paper has argued for the conceptual importance of a multi-scalar approach in the study and interpretation of change in the interrelated ceramic system of production, exchange, and consumption. More importantly, this approach has shifted away from generalised models in the identification of networks as the sole possible framework for addressing past interactions and connectivity in ceramic studies. Apart from the micro-scale study of pottery at an intra-site level, the comparative examination of pottery sherds and/or thin sections from a number of central and east Aegean and western Anatolian sites has enabled the identification of imports and the establishment of a first understanding of the connections between Samos and other contemporary sites and its participation in various networks of interaction.

\section{Acknowledgements}

A great part of the work presented here was carried out while I was a PhD candidate at the Department of $\mathrm{Ar}$ chaeology, University of Sheffield (2014-2018), under the supervision of Prof. Peter M. Day. My PhD research was funded through a three-year scholarship by the Faculty of Arts and Humanities of the same institution. For the collection of data and fieldwork on Samos funding was generously received also from the A.S. Onassis Foundation and the A.G. Leventis Foundation. I would like to thank Assoc. Prof. Ourania Kouka for entrusting me the publication of the ceramic material from the recent excavations at Heraion, as well as the German Archaeological Institute at Athens and the Ephorate of Samos and Ikaria (Ministry of Culture, Greece) for permits to accomplish the original study and sampling of the pottery. The draft of this paper was prepared during a Post-doc Fellowship at Koç University, Research Center for Anatolian Civilizations (ANAMED) in Istanbul. The drawings of the Heraion ceramic vessels were prepared by Christina Kolb and Andreas Kontonis, while the photographs were taken by Chronis Papanikolopoulos (INSTAP-SCEC), unless specified otherwise. Special thanks are owed to Dr Miguel del Pino, Dr Marisol Madrid Fernández and Cristina Fernández de Marcos of the Department of Prehistory, Ancient History and Archaeology (University of Barcelona) for the valuable time they spent explaining the use of the SEM-EDS equipment and for assistance in the interpretation of the data acquired. 


\section{References}

Agouridis, C. 1997. Sea routes and navigation in the third millennium BC Aegean, Oxford Journal of Archaeology 16 (1), 1-24.

Alram-Stern, E. and Horejs, B. (eds.) 2018a. Pottery Technologies and Sociocultural Connections between the Aegean and Anatolia during the 3rd millennium BC, OREA 10, Österreichische Akademie der Wissenschaften-Philosophisch-historische Klasse, Oriental and European Archaeology, Österreichische Akademie der Wissenschaften, Wien.

Alram-Stern, E. and Horejs, B. 2018b. Pottery Technologies in the Aegean and Anatolia during the Third Millennium BC: An Introduction, In: E. Alram-Stern and B. Horejs (eds.), Pottery Technologies and Sociocultural Connections between the Aegean and Anatolia during the 3rd millennium BC. OREA 10, Österreichische Akademie der Wissenschaften-Philosophisch-historische Klasse, Oriental and European Archaeology, Österreichische Akademie der Wissenschaften, Wien, 9-21.

Benzi, M. 1997. The late EBA finds from Vathy Cave (Kalymnos) and their links with the NE Aegean, In: C. G. Dou-

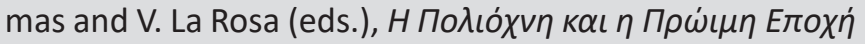

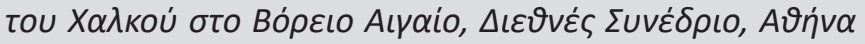

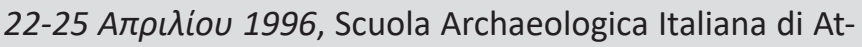
ene, University of Athens, 383-394.

Bernabò Brea, L. 1964. Poliochni, città preistorica nell'isola di Lemnos, I, Monografie della Scuola Archeologica di Atene e delle Missioni Italiane in Oriente 1, Bretschneider, Rome.

Bernabò Brea, L. 1976. Poliochni, città preistorica nell'isola di Lemnos, II, Monografie della Scuola Archeologica di Atene e delle Missioni Italiane in Oriente 3, Bretschneider, Rome.

Blegen, C. W., Caskey, J. L., Rawson, M. and Sperling, J. 1950. Troy I. General introduction. The first and second settlements, Princeton.

Blegen, C. W., Caskey, J. L. and Rawson, M. 1951. Troy II. The third, fourth, and fifth settlements, Princeton.

Broodbank, C. 2000. An Island Archaeology of the Early Cyclades, Cambridge University Press, Cambridge.

Çilingiroğlu, Ç. 2012. The Neolithic Pottery at Ulucak in Aegean Turkey. Organization of Production, Interregional Comparisons and Relative Chronology, British Archaeological Reports International Series 2426, Archaeopress, Oxford.

Day, P. M. and Kilikoglou, V. 2001. Analysis of ceramics from the kiln. In: J. C. Shaw (ed.), A LM IA ceramic kiln in South-Central Crete: function and pottery production. Hesperia Supplements 30, 111-133.
Day, P. M., Kiriatzi, E., Tsolakidou, A. and Kilikoglou, V. 1999. Group therapy in Crete: a comparison between analyses by NAA and thin section petrography of Early Minoan pottery, Journal of Archaeological Science 26, 1025-1036.

Day, P. M., Relaki, M. and Faber, E. W. 2006. Pottery making and social reproduction in the Bronze Age Mesara, In: M. H. Wiener, J. L. Warner, J. Polonsky and E. Hayes (eds.), Pottery and society: the impact of recent studies in Minoan pottery. Gold Medal Colloquium in Honor of Philip P. Betancourt. 104th Annual Meeting of the Archaeological Institute of America, New Orleans, Louisiana, 5 January 2003, Archaeological Institute of America Boston, 22-72.

Day, P. M., Doumas, C. G., Erkanal, H., Kilikoglou, V., Kouka, O., Relaki, M. and Şahoğlu, V. 2009. New light on the "Kastri Group": a petrographic and chemical investigation of ceramics from Liman Tepe and Bakla Tepe, XXX Arkeometri Sonuçları Toplantısı 24, 335-347.

Dobres, M.-A. 2000. Technology and social agency. Outlining a practice framework for archaeology, Blackwell, Oxford and Malden.

Ersoy, E. Y., Helvaci, C. and Palmer, M. R. 2012. Petrogenesis of the Neogene volcanic units in the NE-SW trending basins in western Anatolia, Turkey, Contributions to Mineralogy and Petrology 163, 379-401.

Gait, J., Müller, N. S., Kiriatzi, E. and Baird, D. 2018. Examining the dynamics of Early Bronze Agepottery production and distribution in the Konya Plain of South Central Anatolia, Turkey, In: E. Alram-Stern and B. Horejs (eds.), Pottery Technologies and Sociocultural Connections between the Aegean and Anatolia during the 3rd millennium BC. OREA 10, Österreichische Akademie der WissenschaftenPhilosophisch-historische Klasse, Oriental and European Archaeology, Österreichische Akademie der Wissenschaften, Wien, 105-117.

Galanakis, Y. 2009. What's in a Word? The Manifold Character of the Term Koine and its Uses in the Archaeology of Bronze Age Aegean, In: Y. Galanakis and G. Deligiannakis (eds.), The Aegean and its Cultures. Proceedings of the First Oxford-Athens Graduate Workshop Organized in Oxford, 22-23 April 2005, BAR International Series 1975, Archaeopress, Oxford, 5-11.

Gauss, W. and Kiriatzi, E. (eds.) 2011. Pottery production and supply at Bronze Age Kolonna, Aegina. An integrated archaeological and scientific study of a ceramic landscape, Verlag der Österreichischen Akademie der Wissenschaften, Vienna.

Georgiadis, M. 2012. Kos in the Neolithic and Early Bronze Age. The Halasarna finds and the Aegean settlement pattern, Prehistory Monographs 38, INSTAP Academic Press, 
Philadelphia

Helvacı, C., Ersoy, E. Y., Sozbilir, H., Erkül, F., Sümer, Ö. and Uzel, B. 2009. Geochemistry and 40Ar/39Ar geochronology of Miocene volcanic rocks from the Karaburun Peninsula: implications for amphibole-bearing lithospheric mantle source, Western Anatolia, Journal of Volcanology and Geothermal Research 185,181-202.

Hilditch, J. 2013. The fabrics of the ceramics at Dhaskalio, In: C. Renfrew, O. Philaniotou, N. Brodie, G. Gavalas and M.J. Boyd (eds.), The Settlement at Dhaskalio. The Sanctuary on Keros and the Origins of Aegean Ritual Practice: The Excavations of 2006-2008 Vol. I, McDonald Institute Monograph Series, McDonald Institute for Archaeological Research, Cambridge, 465-482.

Hilditch, J. 2018. The fabric study of the pottery of Dhaskalio and Kavos, In: C. Renfrew, O. Philaniotou, N. Brodie, G. Gavalas and M. J. Boyd (eds.), The Marble Finds from Kavos and the Archaeology of Ritual. The Sanctuary on Keros and the Origins of Aegean Ritual Practice Vol. III, McDonald Institute Monograph Series, McDonald Institute for Archaeological Research, Cambridge, 445-493.

Hood, S. 1981-1982. Excavations in Chios 1938-1955. Prehistoric Emporio and Ayio Gala, Bd. I-II, The British School of Archaeology at Athens. Suppl. Vols. No. 15-16, Thames and Hudson, Oxford.

Horejs, B. 2017. Çukuriçi Höyük 1. Anatolia and the Aegean from the 7th to the 3rd Millennium BC. With contributions by Ch. Britsch, St. Grasböck, B. Milic, L. Peloschek, M. Röcklinger, Ch. Schwall, OREA 5, Austrian Academy of Sciences Press, Vienna.

Horejs, B. Japp, S. and Mommsen, H. 2018. Early Bronze Age Pottery Workshops Around Pergamon. A Model for Pottery Production in the 3rd Millennium BC, In: E. AlramStern and B. Horejs (eds.), Pottery Technologies and Sociocultural Connections between the Aegean and Anatolia during the 3rd millennium BC. OREA 10, Österreichische Akademie der Wissenschaften-Philosophisch-historische Klasse, Oriental and European Archaeology, Österreichische Akademie der Wissenschaften, Wien, 25-61.

Hunt, A. M. W. (ed.) 2016. The Oxford handbook of archaeological ceramic analysis, Oxford University Press, Oxford.

Innocenti, F. and Mazzuoli, R. 1972. Petrology of the IzmirKaraburun volcanic area (West Turkey), Bulletin of Volcanology 36 (1), 83-104.

Joukowsky, M. S. 1986. Prehistoric Aphrodisias. An account of the excavations and artifact studies, Brown University/ Université Catholique de Louvain, Providence/Louvain-laNeuve.

Kibaroğlu, M. and Thumm-Doğrayan, D. 2013. Trojan pithoi: A petrographic approach to provenance of Bronze Age storage vessels from Troy, Applied Clay Science 82, 4452.
Kilikoglou, V. and Maniatis, Y. 1993. Technological study of Neolithic ceramics from Tharrounia and Psachna, In: A. Sampson (ed.), Skoteini Tharrounia: The Cave, the Settlement, and the Cemetery, Athens, 438-441.

Kiriatzi, E., Georgakopoulou, M. and Pentedeka, A. 2011. Pottery production and importation within Aegina's landscape: ceramic petrology, geochemistry, replication experiments and ethnoarchaeology, In: W. Gauss and E. Kiriatzi (eds.), Pottery production and supply at Bronze Age Kolonna, Aegina. An integrated archaeological and scientific study of a ceramic landscape, Verlag der Österreichischen Akademie der Wissenschaften, Vienna, 69-156.

Knappett, C. 2013. Introduction: why networks? In: C. Knappett (ed.), Network Analysis in Archaeology: New Approaches to Regional Interaction, Oxford University Press, Oxford, 3-15.

Knappett, C. and Nikolakopoulou, I. 2015. Inside Out? Materiality and Connectivity in the Aegean Archipelago, In: A.B. Knapp and P. van Dommelen (eds.), The Cambridge Prehistory of the Bronze and Iron Age Mediterranean, Cambridge University Press, Cambridge, 25-39.

Knappett, C. and Kiriatzi, E. 2016. Technological mobilities: perspectives from the eastern Mediterranean - an introduction, In: E. Kiriatzi and C. Knappett (eds.), Human mobility and technological transfer in the prehistoric Mediterranean, Cambridge University Press, Cambridge, 1-17.

Kohl, P. L. 2011. World-Systems and Modelling MacroHistorical Processes in Later Prehistory: an Examination of Old and a Search for New Perspectives, In: T. Wilkinson, S. Sherratt and J. Bennet (eds.), Interweaving Worlds: Systemic Interactions in Eurasia, 7th to 1st Millennia BC, Oxbow Books, Oxford and Oakville, 77-86.

Kouka, O. 2002. Siedlungorganisation in der Nord- und Ostagais wahrend der Fruhbronzezeit (3. Jt. v.Chr.), Internationale Archaeologie 58, Verlag Marie Leidorf $\mathrm{GmbH}$, Rahden.

Kouka, O. 2015. Prehistoric Heraion Reconsidered: glimpses on the excavations 2009-2013 north of the Sacred Road, In: D. Panagiotopoulos, I. Kaiser and O. Kouka (eds.), Ein Minoer im Exil. Festchrift für Wolf-Dietrich Niemeier, Universitätsforschungen zur Prähistorichen Archäologie, Verlag Dr. Rudolf Habelt GMBH, Bonn, 223-242.

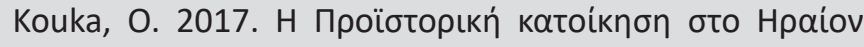

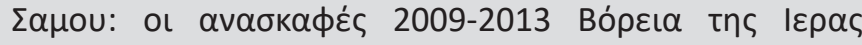

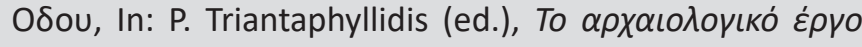

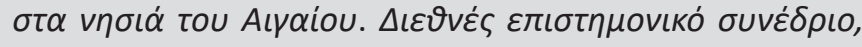

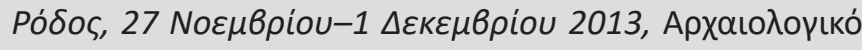

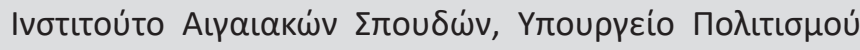

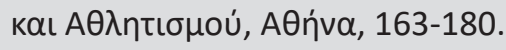

Kouka, O. and Menelaou, S. 2018. Settlement and society in the Early Bronze Age Heraion: exploring stratigraphy, architecture and ceramic innovation after mid- $3^{\text {rd }}$ mil- 
lennium BC, In: E. Alram-Stern and B. Horejs (eds.), Pottery Technologies and Sociocultural Connections between the Aegean and Anatolia during the 3rd millennium BC. OREA 10, Österreichische Akademie der WissenschaftenPhilosophisch-historische Klasse, Oriental and European Archaeology, Österreichische Akademie der Wissenschaften, Wien, 119-142.

Kouka, O. Menelaou, S. and Maniatis, Y. forthocming. Filling in the Puzzle: A Holistic Approach on the Early Bronze Age at the Heraion on Samos, In: S. Marketou and S. Vitale (eds.), The Southeast Aegean/Southwest Coastal Anatolian Region: Material Evidence and Cultural Identity I. The Early and Middle Bronze Age, International Conference, Athens, 12-14 May 2016, Italian School of Athens.

Krijnen, A. 2014. Variability in the production and use of ceramics at Late Bronze Age Troy. A macroscopic and miscroscopic fabric analysis, Unpublished MSc dissertation, Vrije Universiteit Amsterdam.

Kyrieleis, H., Kienast, H. J and H.-J. Weisshaar. 1985. Ausgrabungen im Heraion von Samos 1980/81, Archäologischer Anzeiger 100, 365-418.

Leidwanger, J. and Knappett, C. 2018. Maritime Networks, Connectivity, and Mobility in the Ancient Mediterranean, In: J. Leidwanger and C. Knappett (eds.), Maritime Networks in the Ancient Mediterranean World, Cambridge University Press, New York, 1-21.

Lemonnier, P. (ed.) 1993. Technological choices: transformation in material cultures since the Neolithic, Routledge, London.

Menelaou, S. 2015. The Heraion of Samos under the microscope: a preliminary technological and provenance assessment of the Early Bronze Age II late-III (ca. 2500-2000 $\mathrm{BC})$ pottery, In: Z. Theodoropoulou-Polychroniadis and E. Doniert (eds.), Aegis: Essays in Mediterranean Archaeology Presented to Matti Egon by the Scholars of the Greek Archaeological Committee UK, Archaeopress, Oxford, 2534.

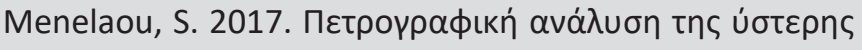

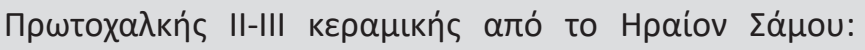

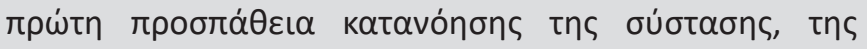

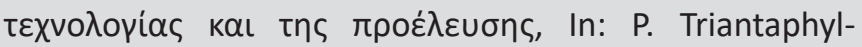

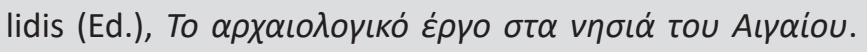

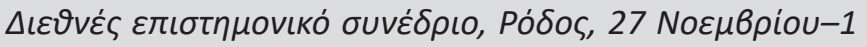

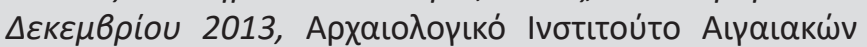

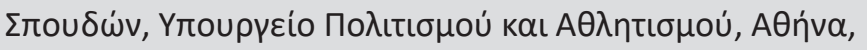
181-194.

Menelaou, S. 2018. A Diachronic Study of the Early Bronze Age Pottery from Heraion on Samos, Greece: An Integrated Approach, Unpublished PhD thesis, University of Sheffield. http://etheses.whiterose.ac.uk/id/eprint/21398

Menelaou, S., Kouka, O. and Day, P. M. 2016. Pottery production and exchange at the Heraion, Samos during the late third millennium BC. First steps in the study of technology and provenance, Journal of Archaeological Science: Reports 7, 480-488.

Mentesana, R., Kilikoglou, V., Todaro, S. and Day, P.M. 2019. Reconstructing change in firing technology during the Final Neolithic-Early Bronze Age transition in Phaistos, Crete. Just the tip of the iceberg? Journal of Archaeological and Anthropological Sciences 11 (3), 871-894.

Milojčić, V. 1961. Die prähistorische Siedlung unter dem Heraion. Grabung 1953 und 1955, SAMOS Band I, Verlag Dr. Rudolf Habelt GMBH, Bonn.

Orton, C. and Hughes, M. 2013 (second edition). Pottery in archaeology, Cambridge University Press, Cambridge.

Ownby, M. F., Druc, I. C. and Masucci, M. A. 2016. Integrative approaches in ceramic petrography, University of Utah Press, U.S.

Papadatos, Y. and Nodarou, E. 2018. Pottery technology(ies) in Prepalatial Crete: evidence from archaeological and archaeometric study, In: E. Alram-Stern and B. Horejs (eds.), Pottery Technologies and Sociocultural Connections between the Aegean and Anatolia during the 3rd millennium $B C$. OREA 10, Österreichische Akademie der Wissenschaften-Philosophisch-historische Klasse, Oriental and European Archaeology, Österreichische Akademie der Wissenschaften, Wien, 287-303.

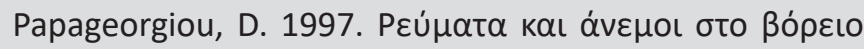

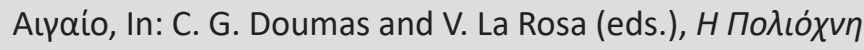

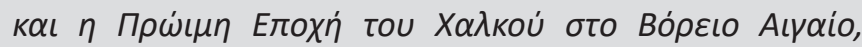

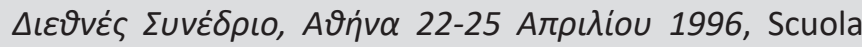
Archaeological Italiana di Atene, University of Athens-

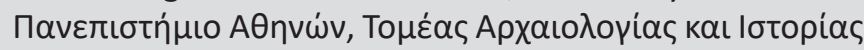

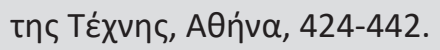

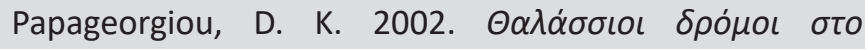

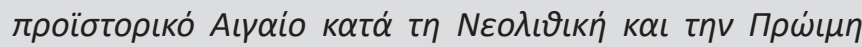

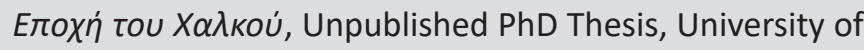
Athens.

Pe-Piper, G., Piper, D. J. W., Kotopouli, C .N. and Panagos, A. G. 1994. Neogene volcanoes of Chios, Greece: the relative importance of subduction and back-arc extension, Geological Society 81, 213-231.

Rice, P. M. 1996. Recent ceramic analysis: 1. function, style, and origins, Journal of Archaeological Research 4 (2), 133-163.

Rice, P. M. 1998. Contexts of Contact and Change: Peripheries, Frontiers, and Boundaries, In: J. G. Cusick (ed.), Studies in Culture Contact: Interaction, Culture Change, and Archaeology, Center for Archaeological Investigations, Occasional Paper No. 25, Carbondale, Southern IIlinois University, 44-66.

Roux, V. 2016. Ceramic manufacture: the chaîne opératoire approach, In: A. M. W. Hunt (ed.), The Oxford hand- 
book of archaeological ceramic analysis, Oxford University Press, Oxford, 102-114.

Şahoğlu, V. 2005. The Anatolian Trade Network and the Izmir region during the Early Bronze Age, Oxford Journal of Archaeology 24, 339-361.

Şahoğlu, V. 2008 Crossing borders: the Izmir region as a bridge between the East and the West during the Early Bronze Age, In: C. Gillis and B. Sjöberg (eds.), Crossing borders: trade and production in premonetary Greece. Proceedings of the 7th, 8th and 9th International workshops Athens 1997-1999, Paul Astroms Forlag, 153-173.

Sibbesson, E., Jervis, B. and Coxon, S. (eds.) 2016. Insight from innovation: new light on archaeological ceramics. Papers presented in honour of Professor David Peacock's contributions to archaeological ceramic studies, Southampton Monographs in Archaeology, New Series 6, The Highfield Press, St. Andrews.

Stein, G. J. 1998. World System Theory and Alternative Modes of Interaction in the Archaeology of Culture Contact, In: J. G. Cusick (ed.), Studies in Culture Contact: Interaction, Culture Change, and Archaeology, Center for Archaeological Investigations, Occasional Paper No. 25, Carbondale, Souther Illinois University, 220-255.

Tartaron, T. F. 2018. Geography Matters: Defining Maritime Small Worlds of the Aegean Bronze Age, In: J. Leidwanger and C. Knappett (eds.), Maritime Networks in the Ancient Mediterranean World, Cambridge University Press, New York, 61-92.
Tite, M. S. 1999. Pottery production, distribution, and consumption: the contribution of the physical sciences, Journal of Archaeological Method and Theory 6 (3), 181-233.

Todaro, S. 2018. Forming techniques and cultural identity in Early and Middle Minoan Crete: multi-layered vessels from a pottery production area at Phaistos, Annuario della Scuola Archaeologica di Atene delle Missioni Italiane in Oriente 95, 129-143.

Vandiver, P. 1987. Sequential slab construction: a conservative southwest Asiatic ceramic tradition, ca. 7000-3000 BC, Paléorient 13 (2), 9-35.

Wilson, D. E. and Day, P. M. 1994. Ceramic regionalism in Prepalatial Central Crete: The Mesara imports at EMIEMIIA Knossos, The Annual of the British School at Athens 89, 1-87.

Wilson, D. E., Day, P. M. and Joyner, L. 1999. EM IIB ware groups at Knossos: the 1907-1908 South front tests, The Annual of the British School at Athens 94, 1-62.

Whitbread, I. K. 2016. Fabric description of archaeological ceramics, In: A. M. W Hunt (ed.), The Oxford handbook of archaeological ceramic analysis, Oxford University Press, Oxford, 200-216.

Yilmaz, D. 2013. A new Early Bronze Age site in the Eastern Aegean: surveys at Bozköy-Hayantepe in the Troad, The Journal of Academic Social Science Studies 6 (5), 857-888. 